Western Washington University

Western CEDAR

$10-1993$

\title{
On Austria's German Identity: A Reply to Margarete Grandner, Gernot Heiss, and Oliver Rathkolb
}

Harry Ritter

Western Washington University, harry.ritter@wwu.edu

Follow this and additional works at: https:// cedar.wwu.edu/history_facpubs

Part of the History Commons

\section{Recommended Citation}

Ritter, Harry, "On Austria's German Identity: A Reply to Margarete Grandner, Gernot Heiss, and Oliver Rathkolb" (1993). History Faculty and Staff Publications. 37.

https://cedar.wwu.edu/history_facpubs/37 


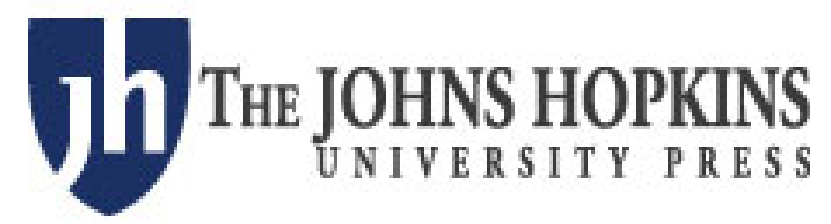

\author{
German Studies Association
}

On Austria's German Identity: A Reply to Margarete Grandner, Gernot Heiss, and Oliver Rathkolb

Author(s): Harry Ritter

Source: German Studies Review, Vol. 16, No. 3 (Oct., 1993), pp. 521-523

Published by: The Johns Hopkins University Press on behalf of the German Studies Association

Stable URL: http://www.jstor.org/stable/1432145

Accessed: 29/10/2014 16:12

Your use of the JSTOR archive indicates your acceptance of the Terms \& Conditions of Use, available at

http://www.jstor.org/page/info/about/policies/terms.jsp

JSTOR is a not-for-profit service that helps scholars, researchers, and students discover, use, and build upon a wide range of content in a trusted digital archive. We use information technology and tools to increase productivity and facilitate new forms of scholarship. For more information about JSTOR, please contact support@jstor.org.

The Johns Hopkins University Press and German Studies Association are collaborating with JSTOR to digitize, preserve and extend access to German Studies Review. 


\title{
On Austria's German Identity: A Reply to Margarete Grandner, Gernot Heiss, and Oliver Rathkolb
}

\author{
Harry Ritter \\ Western Washington University
}

In their response to my essay "Austria and the Struggle for German Identity” (German Studies Review, Special Issue, Winter 1992), Margarete Grandner, Gernot Heiss, and Oliver Rathkolb make several unwarranted claims and one useful reminder. Among the unjustified claims are the suggestion that I consider nationality an "eternal" category of historical understanding (not true - though I do believe that it has proven awfully resilient over the past two centuries) and the assertation that I deny the possible existence of any but a "German" identity for Austria. On the latter point, one should read the original article's entire sentence beginning "Against this backdrop..." (top of page 112) rather than the trimmed and altered version they supply in their footnote 2 . Note, as well, that on page 124 I explicitly state:

There are many possible ways to imagine a history of Austria - one of those, in any case, must be as part of German history, otherwise it is unlikely that any serious and neglected comparative regional history will be done.

Perhaps it may not be entirely clear in the essay, but I think it is usually helpful to think in terms of multiple identities that, of course, may change over time. What I chiefly affirm is that the German aspect of Austrian identity, something which grew increasingly strong between about 1830 and 1940, was repressed after 1945. This had some rather unfortunate consequences for the writing of Austrian history, and perhaps for Austrian civic consciousness as well. Among other things, to quote Radomir Luža once again (see page 113 of my article), denial of the German aspect of Austria's past made it possible for people to regard "Austrian Nazism as an import from Germany and [fail] to acknowledge its Austrian roots." The Erdmann controversy was a product of this circumstance. 
Mainly, however, the three scholars seek to discredit the essay by impugning my alleged ideological motivation, lumping me in the camp of frustrated German nationalists. They state unequivocally that my objective one I allegedly share with Erdmann, Fritz Fellner, and Lothar Höbelt - is “Die Wiedereingliederung der österreichishen Geschichte der Gegenwart mittels der 'gesamtdeutschen' Variante des Deutschnationalismus. . . ." By the deutschnational taint of the terms they choose to characterize this supposed purpose (e.g., Wiedereingliederung, völkischer, rassischer Konzepte), they underscore the allegation. I find their certitude unwarranted by the content of the article or anything else that I have previously said or written.

If I understand my own motives, the paper's origins were far less sinister. It was written because, in late 1991, one of the organizers of a Vancouver conference on German identity suggested that I prepare a report on the Erdmann controversy. Aside from my belief, based on previous research, that German nationalism was indeed strong in Austria in the late nineteenth and early twentieth centuries, and that (for understandable political reasons) this fact had been repressed in Austria after 1945, I came to the task with no covert agenda, political or otherwise. Prior to the conference invitation I had not actually read Erdmann's essays or much of the literature specific to the controversy over his views.

Upon reading Erdmann's essays I did indeed find myself in sympathy with some of his opinions insofar as they might encourage a comparative approach to Austrian and German history within a cultural area studies framework, such as seems at least partly implied in the titles of institutions like the "German Studies Association" and "German Studies Review." I am well aware that the notion of Kulturnationalität is fraught with odious political potential, and that the threat of overgrown nationalism may lurk even behind such currently fashionable and evidently benign notions as "diversity." With proper care, however, the concept might serve as a useful analytical instrument. Incidentally, the three authors complain that I engage in chicanery by proposing rigorous comparison but failing to fulfill the promise. I agree that proposals are no substitute for results, but in this short essay my intent was simply to describe and evaluate the Erdmann controversy and point out, in principle, the desirability of the sort of comparative study that has been discouraged by some attitudes exhibited by Erdmann's critics.

I am not a mind reader and do not know if Erdmann or Fellner wrote out of hidden nationalist motives. They freely admitted that their approaches to history were originally formed at a time when the nation-state was the accepted grid for most research, but that is another matter. It was obvious that some of Erdmann's conceptual categories and the texture of his language would irritate some Austrians who were interested in building a trans-German national identity, but taking this into account I saw no reason to ignore those aspects of 
his viewpoint that seemed useful for technical historical study. I am aware that Höbelt has (justifiably or not) been accused of promoting German nationalist causes but, whatever the case, the same logic would seem to apply to his opinions about the study of the Austrian past.

Lately it has again become fashionable to think that the notion of technical historiography is a smoke screen and that speaking about the past is just a vicarious way of talking about the political present. After the profession's many bouts with Historismus and relativism, most historians would probably agree that an author's political values inevitably inform his historical interpretations in some way. We all know that in the last 100 years politics have often crept into the very driver's seat of scholarship. It seems trivial but perhaps necessary to say, however, that this does not mean that technical history must be a slave to present politics. In the end my three critics seem unable to imagine or explain my desire for a cultural area studies approach in terms other than those of political conspiracy, and perhaps this is yet further testimony to the extent to which a hypersensitive presentism has hamstrung some facets of historical scholarship in postwar Austria.

Erdmann's views have now been debated for almost two decades and most scholars are probably ready to see this particular Historikerstreit laid to rest. In retrospect, however, Grandner, Heiss, and Rathkolb make one point that suggests we have not quite reached the bottom of the barrel. This is the salutary reminder that under the conditions of interwar Europe a German federalist approach to Austrian affairs, which might be construed as a version of the angle of German "diversity" favored by Fellner, was indeed a political and historiographical will-o'-the-wisp. The international circumstances of the 1990s differ fundamentally from those of the 1930s, but it is well to remember the ironic potential of such apparently beneficent ideas as federalism and liberalism. Certainly anyone who wishes to use these concepts as a basis for comparative study would be wise to attend to the paradoxical underside they have sometimes displayed in the past. 